\title{
Transnational Edu-Business in China : A Case Study of Culturalist Market-Making from Finland
}

\section{Dervin, Fred}

2019

Dervin , F \& Simpson , A 2019 , ' Transnational Edu-Business in China : A Case Study of Culturalist Market-Making from Finland ', Frontiers of Education in China , vol. 14 , no. 1 , pp. 33-58 . https://doi.org/10.1007/s11516-019-0002-z

http://hdl.handle.net/10138/311351

https://doi.org/10.1007/s11516-019-0002-z

acceptedVersion

Downloaded from Helda, University of Helsinki institutional repository.

This is an electronic reprint of the original article.

This reprint may differ from the original in pagination and typographic detail.

Please cite the original version. 


\section{Fred DERVIN, Ashley SIMPSON}

\section{Transnational Edu-Business in China: A Case Study of Culturalist Market-Making from Finland}

Abstract This article examines a scholar's discourses related to edu-business in the context of Sino-Finnish edu-business. Based on a critical approach to interculturality, and the decade-long critiques of culturalism, a case study serves as an illustration of the use of the concept of culture by a scholar from Finland to retail Finnish education in China. The results show a reliance on an old and highly criticized conception of culture and a tendency to exoticize and aggrandize Finland, the Finns and Finnish education. Yet a hint at similarities between "Asians" and Finns represents an interesting move from typical differentialist discourses. The article ends with a call for taking interdisciplinarity and ethics into account in edu-business activities in academia.

Keywords edu-business, Finland, culturalism, interculturality, education export Introduction

Edu-business is not a new phenomenon. However, it has developed rapidly over the past decades (Lingard \& Sellar, 2013; Rönnberg, 2017). Edu-business links education with commercial interests, through profit-making and investment based on retailing policies, goods, services and people (Rönnberg, 2017). Its cross-border, transnational, form is often referred to as the Global Education Industry (GEI) (Verger, Steiner-Khamsi, \& Lubienski, 2017). National but also transnational edu-business represented about 43 trillion US dollars in theTransnational Edu-Business in China 35 2014).

Like many other countries, there is, however, an imbalance in terms of educational needs and demands between China and Finland, as Finland is mostly interested in selling to China rather than buying from her (Ryan, 2011). Yet, cooperation between the two countries is officially presented as "The two participants are willing to enhance mutual understanding and trust, to adapt to the development of education in China and Finland and to promote the comprehensive development of bilateral cooperation in education..." (Blogs.helsinki.fi, 2016).

Since Finland actively started exporting its education to the world from the early 2010s onwards, many initiatives have taken place between the Nordic country and China. This quote from a managing director of a private company selling Finnish education abroad summarizes well this phenomenon: "Finland and the Finnish education system have an excellent reputation in China, and we should therefore respond to the need for training as soon as possible" (EduExcellence, 2018).

In autumn 2018 only, the following projects were launched between Finland and China (amongst others):

- EduExcellence, an education service provider owned by the Universities of Applied Sciences in the Helsinki Metropolitan area, created an English-language degree programme on Information Technology Business specifically targeted at Chinese students.

- Education export of elderly care from a University of Applied Sciences to China (Changzhou region) started.

- After opening the Helsinki International Schools (HEI) model kindergarten in Baotou in 2017 HEI Schools units have also been established in Guangzhou and new agreements were signed with partners in Shanghai and Chengdu in autumn 2018. Our article concentrates on a gap that we have identified in the literature on edu-business: the role of academics, specialists in education, in selling (in)directly and implicitly/explicitly flows of services, ideas, and policies to foreign partners. In this article we take the example of a joint education institute between China and Finland where these market-making processes can be clearly observed (Komljenovic \& Lee Robertson, 2017), especially from the Finnish side. 
narrowly specialist readership. They note myths about Finnish education found in the books such as no homework, happiness of all children, no social class. They draw the conclusion that these tell about how the authors of the books view Chinese education but also current societal discussions about it—rather than the complex realities of Finnish education. Despite the fact that the discourses and practices found in the propaganda about Finnish education it is seemingly as popular today as it ever has been (Liu \& Dervin, 2017).

Some of the key factors behind the discourses point to Finnish education being aggressively positioned as an export led strategy by the Ministry of Education and Culture (2010) in Finland, whereby Finnish education is seen as "part of the global service economy" (p. 3). The Ministry of Education and Culture in Finland focuses on competition and a good reputation in "developing Finland as an education-based economy" (p. 3).

As Kapferer (2012) argues "whether they like it or not, (countries) act de facto as a brand-a summary of unique values and benefits" (p. 2). The role of "Finnish nation branding" and Finnish education as an economic export has been discussed by Dervin (2015) whereby Finnish education can be viewed through the context of an economically orientated export strategy (Kantola \& Kettunen, 2012). In addition, the role of Finnish higher education export strategies (Schatz, 2015) have contributed to constructing an image of the country as an educational hyper-brand (Varjo, Simola, \& Rinne, 2013; Dervin, 2015).

Aronczyk (2013) shows that one of the four phases of creating a national brand identity is through education and training. Thus, nation branding and education are seemingly intertwined, not only in terms of the implementation and dissemination of an idea/concept (for example, Finnish education as a nation branding product/service) but also in the processes of formulating and problematizing how the idea/concept comes-into-being. Here, through functioning as ideology nation brands can affect economic, political, social realms through the projection of a perceived national identity whilst at the same time communicating national interests through potentially chauvinistic and antagonistic forms of nationalism (Volcic \& Andrejevic, 2011).

Schatz (2015) and Schatz, Popovic, and Dervin (2015) show how education export discourses, in the example of Finnish education, can be used to create representations of national identity whilst marketing Finnish edu-business. It is 38 Fred DERVIN, Ashley SIMPSON important to note that nation branding can engender ideologies about nationhood (Kaneva \& Popescu, 2011; Kaneva, 2011) and be used to hierarchically position one nation vis-à-vis another nation as well as contributing to the definition of the limits of how nations can be conceived (Volcic, 2008). It is therefore important to pay attention to the ideological and semiotic manifestations of how nation branding comes-into-being in terms of how nation branding is discursively negotiated, constituted, and performed, in relation to edu-business (Manning, 2010; Nakassis, 2012).

\section{Market-Making: The Commodification of Cultural Knowledge in Edu-Business?}

According to Aspers (2011, p. 23), market-making in education consists in a "broader set of processes, which are as much economic as they are cultural, social and political." Li \& Dervin (2018) note how much Finnish edu-business abroad tends to rely on differentialist and culturalist perspectives to retail Finnish education. They explain (p. 14) that Finland is often constructed as "as a different place that has very little in common with other countries-especially in terms of education (Sahlberg, 2014)". The insistence on dissimilarities makes the Nordic country both an "exotic" and "better" place.

The use of culture and especially cultural difference has been under scrutiny by anthropologists, postcolonial scholars and intercultural specialists over the past 20 years (e.g., Wikan, 2002; Appadurai, 2004; Holliday, 2013). The anthropologist Dahlen (1997), in his ethnography of professional interculturalists selling culture in the business context, notes that the latter recycle an 
understanding of culture from an earlier period of anthropology, a period that has been deconstructed and rejected by anthropologists, namely Parsonian structural-functionalism. This perspective viewed "culture as a stable value system, governing human action and manifested in social institutions such as family, corporation and government" (Dahlen, 1997, p. 159). Dahlen notes that, unlike these interculturalists, "in recent anthropology, on the other hand there is a noticeable convergence on greater attention to internal diversity within various kinds of social units" (p. 162). Interculturalists involved in the business world, on the contrary, tend to commodify cultural understanding, insisting on difference. Their system of thought is still dominated by many popular Western-centric

Transnational Edu-Business in China 39 models that claim to describe, analyze and capture what is meant by the intercultural (for example, Byram, 2008; Deardoff, 2009).

Interdisciplinary voices have emerged from different parts of the world over the past decades, to criticize these models and to try to change their culturalist and differentialist tendencies (e.g., Appadurai, 2004; Shi, 2001; McSweeney, 2002). In what follows we discuss "renewed" interculturality as put forward by e.g., Holliday (2010, 2013); Piller (2011) but also Abdallah-Pretceille (1986) and Sarangi (1994). These scholars were highly influenced by the critical work of anthropologists and postcolonial scholars, amongst others (e.g., Appadurai, 2004; Wikan, 2002). This review will serve as guidelines for analysing the way Finnish education is sold by academics to the Chinese.

The first critical aspect relates to a bias that has affected research on culture since the 1950s: the differentialist bias, or an obsession with what makes us different from others, rather than considering the continuum of differences and commonalities (Comaroff \& Comaroff, 2009). Research and practice have not been immune to this incredibly resilient groupthink, often collecting lists of differences to either explain or facilitate intercultural encounters. Of course, differences matter and people are different (across and within "cultures") but they can also share similarities in terms of values, ideas, behaviours, opinions, etc. In many cases two individuals from different "cultures" might share more in common than people from the same country (Abdallah-Pretceille, 1986). Another related issue, hinted at before, is the overreliance on culture as a single analytical category and sole marker of interculturality. Although the concept has been de-re-constructed and deemed potentially counter-productive in many fields of research as it can easily lead to the fixing of traits, habits and opinions and essentialism, it is still very much present in certain strands of educational research (Abdallah-Pretceille, 1986). As such culturespeak (Hannerz, 1999) or the uncritical and narrow way of using the word is still a major problem. Discourses on culture can easily lead to create dichotomies which might emphasize that some people are "good" while others are "bad"; some are "civilised" some "uncivilised" (Philips, 2007).

In the field of intercultural communication scholars like Hall (1959), Hampden-Turner and Trompenaars (1994) and Hofstede (1980), which Holliday calls the "Hofstedian legacy" (Holliday, 2013, p. 6; see McSweeney, 2002 on Hofstede), have tended to rely on the accumulation of knowledge about different

40 Fred DERVIN, Ashley SIMPSON

cultures, often used synonymously with knowledge about "nations." They often lead to stereotypes or simple categorizations, rather than attempting to reflect the complexity of intercultural actors and situations (McSweeney, 2002). Adrian Holliday (2013), amongst others, has shown how discourses of culture can easily lead to moralistic judgments. For instance, the usual do's and don'ts lists of cultural habits, which may look harmless, often hide negative views about the other and sometimes, about the self. These discourses also tend to allow people to easily blame "their" culture or that of the other for what they do or think (Phillips, 2007). This biased consideration towards culture is obvious in many of 
the reports found about Finnish education export. For instance, in one such report, we are told that Finnish teachers who were sent to China to teach were surprised by "the active group of students": "During the week, we had both lectures, exercises and discussions. The group was eager to participate and make questions, Anu (pseudonym) tells us." This surprise is created by the fact that the Finnish teachers probably thought that Chinese students were passive, silent and uncritical as has often been described stereotypically in the literature (Heng, 2018). Another example is found in a quote from a Finnish edu-company established in China that refers to the company as having "a Nordic genome" that leads it to consider equality as its priority — although their schools are "reserved" for rich parents. The use of metaphors related to genetics is often found in culturespeak (Hannerz, 1999).

To summarize, we propose to examine discourses of edu-business in relation to the use and construction of the concept culture. In adopting a critical intercultural perspective (Dervin, 2016; Li \& Dervin, 2018) we acknowledge that there is a continuous need to problematize the instability of the word "culture" and affiliated ideologies. A critical intercultural perspective requires questioning the terms, concepts and notions that we use.

\section{Context of the Study and Data}

The data were collected at a joint conference organized by a Sino-Finnish education institute in China in 2018. The conference brought together researchers, teachers and policymakers. The institute was opened in June 2016 and brings together leading universities and edu-businesses in Finland and China. In 2015 the Finnish Ministry of Education and Culture and the Ministry of Education inTransnational Edu-Business in China 41 China signed a Memorandum of Understanding in five key areas: (1)

Sino-Finnish learning research innovation center (Basic education research and applications, and the facilitation of faculty and student exchanges); (2) Sino-Finnish learning garden experience center (showcasing education research and the involvement of the Chinese and Finnish enterprises in education research and development); (3) Sino-Finnish teacher training center (Professional teacher training); (4) Sino-Finnish education ICT center (Innovative digital solutions in education); and (5) Sino-Finnish double/dual degree center (blogs.Helsinki.fi, 2016a).

The conference is organized alternatively in China and Finland once a year. In 2018, the conference had a specific theme which related to future learning and innovation. About 100 people attended, amongst which less than 20 Finnish scholars. The audience was composed of scholars, students but also decision-makers. In this paper we only concentrate on the Finnish participants' contribution to the conference, as we are interested in their position. Another article will examine the position of the Chinese scholars.

When one looks at the programme of the two-day conference, what strikes us first in the Finnish scholars' presentations is the clear divide between two strands of papers. The first strand covers somewhat conceptual aspects while the other promotes innovations from Finnish education. The first strand covers the followings: the meaning of innovations in education and how these have been implemented in Finnish education (with a clear emphasis on supranational discourses such as those of the OECD and the UNESCO), ICT in Finnish education (discussion paper delivered by an administrator), the "cultural foundations of the success of Finnish education and lessons for Chinese education reform" (conceptual paper delivered by a professor from Finland). The second strand includes: a paper presenting the LUMA center which aims to promote and support STEM education (a branch was opened in Beijing in 2017), a paper about the so-called positive curriculum vitae of the range of skills that helps a child to learn to recognize their various abilities (presented by the creator who is also a scholar), a paper on the "living art exhibition" by its creator (scholar). What surprised us first was the business-like tone and lack of scientific and critical engagement with concepts, methods and education research in 
general.

Also striking is the strong culturalist and essentialist discourses about Finnish

42 Fred DERVIN, Ashley SIMPSON

society, the Finns in general and Finnish education. At the same time, some references were made about Chinese culture and society, which also rely on culturalist ideologies. In the analysis, we concentrate on one of the talks that belongs to the first strand of talks (Cultural foundations of the success of Finnish education). The title already denotes a potential lack of criticality towards Finnish education (the "success"). The abstract for the talk also starts like an advertising leaflet for it, with a somewhat exaggerated synonym for success (triumph): "Since the triumph of Finnish education in PISA, the Finnish lessons have drawn the attention of both education researchers and education practitioners around the world, including China". The objective of this talk was to complement discussions of Finnish education in China by means of more "social and cultural" aspects (excerpt from the abstract). Although the title of the talk only includes a reference to culture, the idea of the social (which is not defined) is omnipresent. It is important to note that the scholar specializes in education management (higher education) and holds a $\mathrm{PhD}$ in administrative science. S/he has written very little on (inter-)cultural approaches to education. In our paper we use excerpts taken from this presentation as it represents the archetype of Finnish edu-business discourses from a scholar's perspective. The excerpts and images used are presented verbatim.

\section{Metadiscourses on the Concept of Culture: Typical Culturalist and Differentialist Perspectives}

In this first analytical section we examine how the speaker uses and problematizes the concepts of culture at a meta-level. This will give us indications of his/her theoretical and methodological approach to and use of the concept.

\section{Excerpt 1}

01. Before talking about the cultural values one needs to have an understanding about 02 . culture there is no unified definition of culture but generally it is called the collective 03 . value of the mass also the author of the book he talks that culture is a process which 04 . each of us has been subjected from birth so when we are born in one country we also 05 . carry on some kind of cultural genes

Transnational Edu-Business in China 43

Excerpt 1 starts with the speaker seemingly opening up a discussion on what is meant by culture (line 1 to line 3 ). It is widely accepted that culture is a polysemic notion (Dahlen, 1997). Seemingly the speaker hints at this understanding of culture when s/he explains that "there is no unified definition of culture" (line 2). The speaker then goes onto make reference to a book Finland, Cultural Lone Wolf (Lewis, 2005) which we will analyse in-depth in the subsequent sections. The metadiscourses about Finland, and about the notion of culture more generally, that are found within the book, are used by the speaker to frame an essentialist conceptualisation of culture. By essentialist or essentialism we mean discourses that "limit self and/or other to a single identity, a single story ('their essence')" (Dervin, 2016, p. 114). The speaker describes culture as "collective value of the mass" (line 2 and line 3 ) yet it is unclear what s/he means by "the mass" and who determines who is represented as "the mass." The speaker might be hinting at a normative understanding of culture which in turn could imply a static and singular conceptualisation and understanding of culture. The speaker goes on to reinforcing this notion by saying "culture is a process which each of us has been subjected from birth" (line 3 and line 4 ). This understanding of culture fails to grasp the ways in which one's identity is constantly transformed through interactions, experiences and encounters (Holliday, 2013). The speaker also fails to grasp the notion of intersectionality, an increasingly accepted paradigm, expressing the productive effect that identity 
markers, such as gender, profession, social class, and age, have on the constitution of multiple identities within the self- not just "culture" (Piller, 2017). The speaker goes on to further evoking essentialist discourses by asserting, one, "we are born in one country" (line 4), which, not only renders a simplistic reading of culture-rejecting the notion that people can have multiple identities and cultures-but explicitly defines culture as determined by the nation state. Two, the speaker proceeds to claim that "we also carry on some kind of cultural genes" (line 4 and line 5), where "genes" implies a biological reading and interpretation of cultural phenomena- a typical metaphor to describe culture as a pure essence (Wikan, 2002). In his book Postmodernity and its discontents Zygmunt Bauman's (1997) first chapter is titled "The dream of purity." Bauman sketches out a sociological archaeology of purity of culture by arguing, Purity is an ideal; a vision of the condition which needs yet to be created, or such as

\section{Fred DERVIN, Ashley SIMPSON}

needs to be diligently protected against the genuine or imagined odds. Without such a vision, neither the concept of purity makes sense, nor the distinction between purity and impurity can be sensibly drawn. (Bauman, 1997, p. 5)

What people characterize as filth and clean, is thus bound by socio-political notions of order and disorder (Bauman, 1997). Thus, the conceptualisation of the ideal engenders logics of sameness/difference which socio-politically and symbolically function to produce and reproduce the notion of the local and the stranger (Bauman, 1997). Bauman (p. 12) succinctly articulates the historicity of "the problem of strangers" and how purity can lead to racism, genocide and destruction through nationalistic ideals. These are important symbolic considerations when the speaker mentions the word "genes" which evokes such a biological interpretation of culture.

In Except 2 below the speaker goes on to discuss the concept of culture at a metalevel.

\section{Excerpt 2}

01 . So why is the cultural foundation so important because understanding the cultural 02. foundation of both systems we can better understand each other we can learn better 03 . from each other and even for one country if we want to learn foreign experience it's 04 . very important we first understand who we are and what are our core values so we 05 . never forget our tradition before we learn from others and a successful learning of 06. foreign experience lies matching the foreign experience with a domestic value system

Excerpt 2 starts with the speaker exploring the notion of a cultural foundation. As Li and Dervin (2018) note in their book that global education metadiscourses often translate power relations. The speaker utters "we can better understand each other and learn better from each other" (line 2 and line 3). Learning from each other can exacerbate unequal power relations as it perhaps assumes that one country/context/group has some notion of knowledge/expertise/skill-set and so forth, that the other does not have. Thus, this can create superior and inferior power dynamics based upon comparisons of e.g., cultures (in this instance Finnish educators could be viewed as being superior whereas the audience could be viewed as being inferior). Here the symbolic exchanges between the groups

Transnational Edu-Business in China 45 are not equalised as this could result in the superior group speaking for and/or over the other. Notwithstanding, these power relations can invoke a normatively static understanding of concepts and discourses found within the relations. The speaker goes on to explain that "if we want to learn foreign experience (sic)" (line 3), in the singular denoting that there is one form of foreign experience, perhaps one type of the foreign[er], again making the essentialist error. Continuing along the same line, the speaker claims, "it's very important we first understand who we are and what are our core values" (line 3 and line 4), failing 
to problematise the simplistic notion of "who we are" and "our core values." Who decides who "we" are? Who decides the core values and for what purpose? Though the answers to these questions are not clear, the speaker continues the narrative of comparison, "so we never forget our tradition before we learn from others" (line 4 and line 5). The speaker again reduces tradition to one essence, one narrative, thus marking essentialism. The speaker extends this thought, "successful learning of foreign experience lies matching the foreign experience with a domestic value system" (line 5 and line 6), juxtapositioning the foreign and the domestic, which invariably engenders comparisons in this case, between the context of China and Finland, and calls for "matching" the two "value systems". The speaker focuses on producing discourses demonstrating a differentialist bias-focusing on differences rather than similarities. Arguably, though focusing on and imposing the notion of difference, the speaker actually engenders more differences between the contexts than similarities.

Excerpts 1 and 2 illustrate the ways essentialist interpretations of culture can be framed within edu-business narratives. The speaker's overt fixation on the foreign and the domestic here reproduces essentialisms about China and Finland. Focusing on these juxtapositions can reinforce differentialist biases and power relations (Appadurai, 2004).

It is also important to note with Bauman that the marketisation and commodification of society has produced waste (as opposed to the idea of the pure) and it is this disposability of objects that we often discard (Bauman, 1997). Bauman (1997) argues,

Since the criterion of purity is the ability to partake in the consumerist game, those left outside as a "problem", as the "dirt" which needs to be "disposed of," are flawed consumers-people unable to respond to the enticements of the consumer market

\section{Fred DERVIN, Ashley SIMPSON}

because they lack the required resources, people unable to be "free individuals" according to the sense of "freedom" as defined in terms of consumer choice. They are the new "impure," who do not fit into the new scheme of purity. Looked at from the now dominant perspective of the consumer market, they are redundant - truly "objects out of place." (Bauman, 1997, p. 14)

Bauman is not just talking about the materiality of objects here but also this logic can be transferred to people, relations and concepts (such as culture). Bauman's work can be particularly illuminating in terms of how Excerpts 1 and 2 mark the strategic use of the concept of culture. The matching of the value systems the speaker talks about in Excerpt 2 and the speakers' earlier utterances about culture in Excerpt 1 show how the speaker, perhaps purposely, fails to contextualize the idea of culture and cultural values and instead relies on assumptions and generalizations to convey his/her narrative. Here edu-business illustrates the construction of "objects out of place" as one day these relations, people and concepts will be disposed-of and will be replaced by different ideas, people and concepts from other contexts. These "objects out of place" are constituted through binary, static (normative) and essentialist interpretations. Culture, although is it uttered as ubiquitous by the speaker, is seemingly made redundant-something that can mean everything and nothing at the same time. The next section problematizes further the speaker as an active participant in the consumerist context of edu-business and the wider socio-political implications of discourses about culture.

\section{Culturalist Discourses on Finland: Selectively "Remarkable" and Exotic \\ Excerpt 3}

01. Now let's go shortly over Finnish culture it is such an important issue we don't have time 02 . for an introduction in a twenty-minute lecture talking about culture can be very 03 . comprehensive and a complicated issue so I mainly refer to the book here it was 04. published in 2005 and with we are getting the book translated into Chinese even 05. though this book is not about education it is very relevant to education research in order 06. to understand Finnish education andTransnational Edu-Business in China 47 
the cultural foundations of Finnish education to 07. understand Finnish culture one cannot escape Finnish history [Figure 1]

Excerpt 3 starts with the speaker talking about Finnish culture (line 1). The speaker goes on to discussing a publication which s/he uses in the presentation. "The book here" (line 3) refers to a publication titled Finland, Cultural Lone

Wolf (Lewis, 2005) - a non-academic book presenting an image of Finland constructed as follows (book blurb):

Finland, Cultural Lone Wolf is the story of an accomplished nation and her extraordinary people. Pursuing a "Lone Wolf" policy, Finland raised itself from a struggling, war-battered state in 1945 to one of the most developed countries in the world. The exponential rise of Nokia from tire and timbers to leading the world's telecommunication industry is indicative of the Finns and their characteristic business style. These remarkable people speak a language unique in its origins and have kept their cultural identity intact despite the influences of powerful neighbours, Sweden and Russia. The tone of the book is set here with the use of hyperboles ("her extraordinary people," "these remarkable people"), and an insistence on difference ("their characteristic business style," "[they] speak a language unique in its origins"). It is important to note that the author is a businessman who has lived in Finland for decades. He published the book in the early 2000s at the height of Nokia's global fame - a Finnish telecommunication company that collapsed in the early 2010s. This is not the first time that a scholar uses this book in promoting Finnish education. As such many of the ideas contained in this book have been discussed extensively by leading Finnish educator Pasi Sahlberg (2006, 2007, 2010) as reasons why Finland has scored so highly in the OECD's PISA rankings. Sahlberg argues that certain social characteristics have enabled Finland to develop as one of the world's best education systems,

these include such cultural hallmarks as a law-abiding citizenry, trust in authority, commitment to one's social group, awareness of one's social status and position, and a patriotic spirit. (Sahlberg, 2007, p. 148) In a 2006 publication titled Education reform for raising economic competitiveness Sahlberg (2006, p. 278) goes on to argue that "Finland is socially and culturally homogenous." These are perhaps some of the "the cultural48 Fred DERVIN, Ashley SIMPSON foundations of Finnish education" (line 6) that the speaker is telling the audience of. Yet, Lewis' and Sahlberg's publications and the speakers' remarks are deeply problematic. First and foremost, these discourses and publications mark clear that

culturalism is here understood as 'using culture as an explanation for everything that a representative of another country does, thinks, etc. while ignoring the fact that other reasons might apply. Culturalism also summarizes the ideas of culture as an excuse and culture as an alibi. (Dervin, 2016, p. 113)

Lewis' (2005) work is framed within Hall's (1959) and Hofstede's (1980) heavily criticised interpretations of communication which focus on cultural descriptions and generalisations rather than critical forms of analysis. The ways certain contexts are conceptualised in these approaches is often characterised by essentialism whereby culture is usually a synonym for country. The focus on the latter here demarcates political overtures in the ways cultural representations can be tools designed for building national (nation-state) identities and/or nationalistic identities (McSweeney, 2002). When Sahlberg talks of a 'patriotic spirit' (Sahlberg, 2007, p. 148) one should not take these words lightly in terms of how discourses about Finnish education also contain representations about Finland being homogenous. In Excerpt 3 the speaker goes on to say 'to understand Finnish culture one cannot escape Finnish history" (line 6 and line 7), these claims along with Figure 1 below and Excerpt 4 show how historical narratives can be distorted for politico-economic purposes.

Figure 1 A Presentation Slide Used by the Speaker

Transnational Edu-Business in China 49

\section{Excerpt 4}

08. I cannot give a lecture about Finnish history many Finnish Professors here know much 09. more than me so here is a short list of a landscape of major 
events in Finnish history as 10. you can see over the previous centuries Finland has experienced hardship a lot of 11 . challenges so Finland is still new last year it celebrated one-hundred years of 12. independence so many cultural elements core values and beliefs of Finland come from 13. the history the hardship I will skip this [Figure 1] if you are interested in these issues I 14. believe you can easily look at Finnish history from the internet from relevant books Excerpt 4 starts with the speaker saying "I cannot give a lecture about Finnish history" (line 8), the audience are left thinking is this an honest assessment by the speaker or is it a possible apology for the selective history s/he goes onto present? The speaker goes onto talk about the way Finnish cultural values have been shaped by Finland's history (line 12 to line 13), in particular, the speaker mentions "hardship a lot of challenges" (line 10 and line 11) and "hardship" (line 13) which evoke sentiments that the audience should in some way feel sorry for Finland. This discourse is directly reminiscent of Lewis' aforementioned discourses. Though these discourses are in no way naïve, the focus on hardship here has historically functioned symbolically as one of the ways Finland has constructed its national identity contra its so-called aggressor, The Soviet Union/Russia (Eskola et al., 2011). In Figure 1 the speaker includes two lines in his/her presentation which state "1939-1940 winter war (against Soviet Union invasion)" and "1941-1944 Continuation War during WWII (against Soviet Union)." The wording of these lines and the contents contained in parenthesis is significant, the speaker chooses to word these lines, in both instances, as "(against Soviet Union)" without saying, either orally in his/her speech or visually on the presentation slide that during this time Finland was actively supporting and cooperating with Nazi Germany. Such discourses can serve to reproduce the silent history of holocaust denial within Finland, in addition to, denial about Finland's role in supporting Nazi Germany militarily during World War 2 (For example Finland's active role in The Leningrad Blockade between 1941-1944) (Worthen, 2009; Muir \& Worthen, 2013). Another consideration to note is articulated by Loftsdóttir and Jensen (2016) who show the dangers of exceptionalism discourses about values and concepts within Nordic countries

50 Fred DERVIN, Ashley SIMPSON

such as Finland which can actually serve to mask or quieten certain issues surrounding equality and social justice within the country of Finland (Simpson \& Dervin, 2017; Simpson, 2018).

Excerpt 3 and Excerpt 4, in addition to Figure 1, illustrate the need to continually problematise history and culture when they are used for economic purposes within the context of edu-business. In these instances, selectivity can be deeply problematic as cultural essentialisms and historical (mis)representations can actually reproduce nationalist discourses and lead to forms of xenophobia. Arguably, in Excerpt 3 and Excerpt 4 the speaker functions as a parrot in that s/he reproduces generalisations about the country of Finland without problematising them or explaining them to the audience. It is important to move away from generalisations of how culture and history appear and instead continually question what culture and history actually mean within different contexts.

\section{Excerpt 5}

Figure 2 used by the speaker is directly taken from Finland, Cultural Lone Wolf (Lewis, 2005) as it appears in the book on page 68.

Figure 2 A Presentation Slide Used by the Speaker

01. There are also some kinds of discussions in Lewis' book about comparing western and 02. eastern cultures to Finland. Finnish culture is very interesting and unique dilemma in 03 . Finnish culture west culture values but eastern in the way they communicate is eastern style 04. they share basic values with westernTransnational Edu-Business in China 51 countries but when it comes to communication style 05. Finns look like Chinese very modest, silent, they do not interrupt the speakers and I have 06 . copy paste the figure [Figure 2] from the book of what the values Finns share with western 
07. European people and in communication they are similar to the Asians I think this is very 08 . interesting it costs a lot of traditions

Excerpt 5 starts with the speaker, based on Lewis's book, comparing Eastern and Western cultures which echoes the thinking of Hall (1959) and Hofstede (1980), and which has been criticized by postcolonial scholars such as Appadurai (2004). The speaker speaks of "comparing western and eastern cultures" (line 1 and line 2) yet with the critical approach to intercultural communication in mind (Dervin, 2016, 2017; Holliday, 2011, 2013; Piller, 2017) "cultural comparisons can create dichotomies between the 'good' and 'bad,' the 'civilized' and 'uncivilized,' and the 'same' and the 'other'” (Holliday, 2011, p. 39).

Comparisons can also

contribute to ethnocentrism (believing that our culture is better than others), establish power imbalance, patronize the other, close doors to our environment, and hide and justify negative actions (attacks against freedom of speech, violation of human rights, misogyny, and so on). (Dervin, 2016, p. 11)

Nonetheless, the speaker explains that "Finnish culture is very interesting and unique dilemma [sic] in Finnish culture, west culture values but eastern in the way they communicate is eastern style" (line 2 and line 3 ). The speaker assumes what "eastern" and "western" are without contesting these notions. However focusing on such comparisons "can trap the other in some artificial uniqueness and 'freeze' him/her in a state of 'permanent otherness"' (Levinas, 1969 as cited in Dervin, 2016, p. 19). By uttering these discourses the speaker engenders othering, or "turning self and other into an 'other' by using stereotypes, representations, and prejudices. Othering often leads to hierarchizing the world" (Dervin, 2016, p. 115; Holliday, 2013). In reproducing essentialisations and generalisations about Finland, simultaneously the speaker others Asia/Asian people (with perhaps an explicit reference to China/Chinese people). This can be illustrated by some of the examples used in Figure 2 whereby Asian values are characterized as "hierarchies, males dominate, inequality" and the communication style as "thinks in silence, introvert and quiet" amongst others. 52 Fred DERVIN, Ashley SIMPSON These labels and categories are laden with generalisations which may or may not be true but are nonetheless used to describe how people are. For example, the speaker mentions: "Finns look like Chinese very modest, silent, they do not interrupt the speakers" (line 5). Simultaneously in uttering these words the actions/beliefs/values of Finns and Chinese become generalized. These representations function in othering the audience as it might be assumed that everyone listening to the speaker has the traits the speaker is referring to. The speaker goes onto say "in communication they are similar to the Asians I think" (line 7). It is also not particularly clear what the speaker means by "Asian" as many contexts within Asia differ greatly within and between countries (geographically, spatially, linguistically and so forth).

Dervin (2016) reminds us that othering functions in "creating a boundary between different and same, insiders and outsiders" (p. 45). It is this artificial connection of sameness that the speaker uses in Excerpt 5 as a potential strategy as part of his/her edu-business narrative. Arguably the speaker does this to try and convince the audience of the similarities the two contexts have to try and foster edu-business cooperation between Finland and China. The speaker's argument is problematic as it is based on descriptive imaginaries of how the Finnish and Chinese contexts are, which can be misleading and inaccurate. These descriptive imaginaries can be manipulated within the context of edu-business to mystify and essentialize China and Finland. In some cases the imaginary of similarity could be used to hierarchically situate the two countries as being better than others (e.g., the USA). These discourses and narratives must be contested as they can lead to power imbalances, nationalism and ethnocentrism.

\section{Discussion and Conclusion}

This article represents an attempt at examining a scholar's discourses related to edu-business. As a reminder, we do not intend to generalize this discourse to all scholars involved in edu-business (from Finland or elsewhere). Our interest was 
to describe a case study, within the specific context of a joint initiative between China and Finland, gathering different kinds of actors. Such events, such initiatives are spreading around the world, and considering the current mix of business and politics in education research today, it is essential to identify and analyse critically discourses emerging on such occasions. Transnational Edu-Business in China 53 What our study shows is that the scholar in our case study, who is not a specialist in (inter-)cultural issues in education, uses a weak knowledge base in e.g. anthropology, post-colonial studies and intercultural communication. By so doing s/he falls into the trap of culturalist market-making. As the scholar relies mostly on a book that would be classified as essentialist and culturalist by intercultural experts and anthropologists, his/her observations about Finnish culture to explain and understand the Finnish education "miracle" appears biased, uncritical and embellished. At the same time, the scientific credibility of her/his statements based on mere culturespeak (Hannerz, 1999), is questionable, since the author of the book s/he uses is not a scholar and the book was published over 10 years ago - a different era for Finland. The purpose this seems to serve is to confirm in front of the Chinese audience that Finland, Finns and Finnish education are "exotic" and "remarkable" at the same time. The hint at similarities between Asians and Finns in terms of communication style represents an interesting move from a typical differentialist discourse. At the same time, it might be considered as a "pitching and branding strategy" (Rönnberg, 2017). What our study demonstrates is that there is a need to produce more critical research on edu-business. Research on the stakeholders involved is essential. In our paper, we showed that the presentation under review uses problematic discourses of culture that have been studied critically, deconstructed and rejected in other fields of research (intercultural communication, anthropology but also linguistics, amongst others). It would be important for scholars wishing to sell their own education elsewhere to be aware of these critiques.

Interdisciplinarity is often considered as an important part of researchers' work, especially in a multifaceted field like education. However, interdisciplinarity requires awareness of the new, different paradigms available in other fields and of the history of concepts/notions, theories and methodologies. Discourses of culture in edu-business, especially those that place hierarchies between people (better/worse; more civilized/less civilized; more hardworking/less hardworking, etc.), tend to fall into culturalist traps that could be easily avoided if such archeological work was done before engaging with potential buyers. This is also part of education researchers' ethical responsibilities: the potential manipulation of discourses of culture for market-making should be questioned. 54 Fred DERVIN, Ashley SIMPSON

\section{References}

Abdallah-Pretceille, M. (1986). Vers une pédagogie interculturelle [Towards intercultural education]. Paris, France: Anthropos.

Appadurai, A. (2004). The capacity to aspire: Culture and the terms of recognition. In V. Rao $\&$ Walton, M. (Eds.), Culture and public action (pp. 59 $\square 84$ ). Palo Alto, CA: Stanford University Press.

Aronczyk, M. (2008). "Living the brand": Nationality, globality, and the identity strategies of nation branding consultants. International Journal of Communication, 2, 25. Retrieved from http://ijoc.org/index.php/ijoc/article/view/218

Aronczyk, M. (2013). Branding the nation: The global business of national identity. Oxford, UK: Oxford University Press.

Aspers, P. (2011). Markets. Cambridge, UK: Polity Press.

Ball, S. J. (2012). Global education Inc.: New policy networks and the neoliberal imaginary. London, UK: Routledge.

Bauman, Z. (1997). Postmodernity and its discontents. New York, NY: New York University Press.

Blogs.helsinki.fi. (2016). Memorandum of cooperation between The Ministry of Education of the People's Republic of China and The Ministry of education and Culture of the Republic of Finland on strengthening comprehensive cooperation on education. Retrieved From https://blogs.helsinki.fi/sino-finnish-collaboration-edu/files/2016/04/Memorandum-of-Coop eration-Ministries-China-Finland-2015.pdf

Byram, M. (2008). Defining and assessing intercultural competence. Clevedon, UK: 
Multilingual Matters.

Comaroff, J. L., \& Comaroff, J. (2009). Ethnicity, Inc. Chicago, CL: The University of

Chicago Press.

Dahlen, T. (1997). Among the interculturalists: An emergent profession and its packaging of knowledge. Philadelphia, PA: Coronet Books.

Deardoff, D. (Ed.). (2009). The SAGE handbook of intercultural competence. New York, NY: Sage.

Dervin, F. (2015). Country "hyper-branding" and the internationalization of higher education in Finland: Is the (R)evolution of interculturality coming? Educational Practice and Theory,

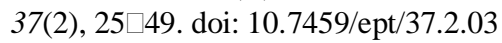

Dervin, F. (2016). Interculturality in education: A theoretical and methodological toolbox.

London, UK: Palgrave Macmillan.

Dervin, F. (2017). Critical interculturality. Newcastle, UK: CSP.

EduExcellence. (2018). Press release 24/10/2018: Finnish education customised for Chinese students in Beijing. Retrieved from https://www.eduexcellence.fi/2018/10/24/pressrelease24-10-2018-finnish-education-customised-for-chinese-students-in-beijing/

EDUFI. (2018). Finnish National Agency for Education to boost education exportTransnational Edu-Business in China 55

—Education Finland growth programme launched. Retrieved from https://www.oph.fi/

english/current_issues/101/0/finnish_national_agency_for_education_to_boost_education_e

xport_education_finland_growth_programme_launched

Eskola M., Räisä T., \& Stenius H. (2011) Identity construction and modernity in Finland:

Borders, ruptures and significant others. In A. Ichijo (Ed.), Europe, nations and modernity

(pp. 183 $\square 207)$. London, UK: Palgrave Macmillan.

Forbes.com. (2016). The magic of Finnish schooling: Now with a management twist.

Retrieved from http://www.forbes.com/sites/lizryan/2016/08/21/the-interviewerdidnt-likeit-

when-i-started-asking-questions/\#2887af951c12

Forestier, K., \& Crossley, M. (2014). International education policy transfer-borrowing both ways: The Hong Kong and England experience. Compare: A Journal of Comparative and International Education, 45(5), 664 $\square 685$. doi: 10.1080/03057925.2014.928508

Gu, M. Y. (2004). 中国教育的文化基础 [The cultural basis of the Chinese education]. 太原, 山西: 山西教育出版社 [Taiyuan, China: Shanxi Education Press].

Hall. E. T. (1959). The silent language. New York, NY: Doubleday.

Hampden-Turner, C., \& Trompenaars, A. (1993). The seven cultures of capitalism: Value systems for creating wealth in the United States, Japan, Germany, France, Britain, Sweden, and the Netherlands. New York, NY: Doubleday.

Hannerz, U. (1999). Reflections on varieties of culture speak. European Journal of Cultural

Studies, 2(3), 393 4407.

Heng, T. T. (2018). Different is not deficient: Contradicting stereotypes of Chinese international students in US higher education. Studies in Higher Education, 43(1), $22 \square 36$. doi: 10.1080/03075079.2016.1152466

Hofstede, G. (1980). Cultures and organizations: Software of the mind. New York, NY:

McGraw-Hill Education.

Holliday, A. (2013). Understanding intercultural communication: Negotiating a grammar of culture. London, UK: Routledge.

Johnson, D. (2006). Comparing the trajectories of educational change and policy transfer in

developing countries. Oxford Review of Education, 32(5), 679 $\square 696$. doi: 10.1080/

03054980600976411

Kaneva, N. (2011). Nation branding: Toward an agenda for critical research. International

Journal of Communication, 5. Retrieved from https://ijoc.org/index.php/ijoc/article/ view/704

Kaneva, N., \& Popescu, D. (2011). National identity lite: Nation branding in post-Communist Romania and Bulgaria. International journal of cultural studies, 14(2), $191 \square 207$. https://doi.org/10.1177/1367877910382181

Kantola, M., \& Kettunen, J. (2012). Integration of education with research and development and the export of higher education. On the Horizon, 20(1), 7ロ16. doi: 10.1108/ 10748121211202026

Kapferer, J. N. (2012). The new strategic brand management: Advance insights and strategic thinking. London, UK: Kogan Page. 56 Fred DERVIN, Ashley SIMPSON

Komljenovic, J., \& Lee Robertson, S. (2017). Making global education markets and trade. Globalisation, Societies and Education, 15(3), 289 $\square 295$. doi: 10.1080/14767724.2017. 1330140

Latimes.com. (2016). Finland's secret to success in education: Treating teachers as professionals. Retrieved from http://www.latimes.com/opinion/readersreact/la-le-0322tuesdayfinland-education-20160322-story.html

Lewis, D. R. (2005). Finland, cultural lone wolf. London, UK: Intercultural Press.

Li, Y., \& Dervin, F. (2018). Continuing professional development of teachers in Finland. 
London, UK: Palgrave MacMillan.

Lingard, B., \& Sellar, S. (2013). The OECD and Global Governance in Education. Journal of Education Policy, 28(5), 710 $\square 725$. doi: 10.1080/02680939.2013.779791

Liu, H., \& Dervin, F. (2017). "Education is a life marathon rather than a hundred-meter race": Chinese "folk" comparative discourses on Finnish education. Compare: A Journal of Comparative and International Education, 47(4), 529 544 . https://doi.org/10.1080/ 03057925.2016.1257351

Loftsdóttir, K., \& Jensen, L. (Eds.). (2016). Whiteness and postcolonialism in the Nordic region: Exceptionalism, migrant others and national identities. London, UK: Routledge. Manning, P. (2010). The semiotics of brand. Annual Review of Anthropology, 39(1), 33-49. doi: 10.1146/annurev.anthro.012809.104939

McSweeney, B. (2002). Hofstede's model of national cultural differences and their consequences: A triumph of faith—a failure of analysis. Human relations, 55(1), 89 $\square 118$. doi: 10.1177/0018726702551004

Ministry of Education and Culture. (2010). Finnish education export strategy: Summary of the strategic lines and measures. Retrieved from http://www.minedu.fi/export/sites/default/ OPM/Julkaisut/2010/liitteet/okm1

Muir, S., \& Worthen, H. (Eds.). (2013). Finland's Holocaust: Silences of history. London, UK: Springer.

Nakassis, C. (2012). Brand, citationality, performativity. American Anthropologist, 114(4), 624 $\square$ 638. doi: $10.1111 /$ j.1548-1433.2012.01511.x

Niemi H., Toom A., Kallioniemi, A. (Eds.). (2016). Miracle of education: The principles and practices of teaching and learning in Finnish schools. Rotterdam, the Netherlands: Sense. Nordic.businessinsider.com. (2016). Finland has one of the best education systems in the world-here are 4 things it does better than the US. Retrieved from http://nordic.

businessinsider.com/finlandhas-one-of-the-best-education-systems-in-the-world--here-are-4 -things-it-does-better-than-the-us-2016-11/

OECD. (2004). Learning for tomorrow's world: First results from PISA 2003. Paris, France: OECD Publishing. http://dx.doi.org/10.1787/9789264006416-en

OECD. (2006). Messages from PISA 2000. Paris, France: OECD Publishing. http://dx.doi.org/ 10.1787/9789264018761-en

OECD. (2007). PISA 2006: Science competencies for tomorrow's world Volume 1: Analysis.

Paris, France: OECD Publishing. http://dx.doi.org/10.1787/9789264040014-enTransnational Edu-Business in China 57

OECD. (2010). PISA 2009 Results: What students know and can do: Student performance in reading, mathematics and science. Paris, France: OECD Publishing. http://dx.doi.org/ 10.1787/9789264091450-en

Philips, A. (2007). Multiculturalism without culture. Oxford, UK: Oxford university Press.

Piller, I. (2017). Intercultural communication: A critical introduction. Edinburgh, UK:

Edinburgh University Press.

Rönnberg, L. (2017). From national policy-making to global edu-business: Swedish edu-preneurs on the move. Journal of Education Policy, 32(2), 234 $\square 249$. doi: 10.1080/ 02680939.2016 .1268725

Ryan, J. (Ed.). (2011). China's higher education reform and internationalisation. London, UK: Routledge.

Sahlberg, P. J. (2006). Education reform for raising economic competitiveness. Journal of Educational Change, 7(4), 259 $\square 287$. doi: 10.1007/s10833-005-4884-6

Sahlberg, P. J. (2007). Education policies for raising student learning: The Finnish approach.

Journal of Education Policy, 22(2), 147 $\square$ 171. doi: 10.1080/02680930601158919

Sahlberg, P. J. (2010). Educational Change in Finland. In A. Hargreaves, A. Lieberman, M.

Fullan, \& D. Hopkins (Eds.), Second international handbook of educational change

(pp. 323ロ348). Dordrecht, the Netherlands: Springer.

Sahlberg, P. J. (2014). Finnish lessons 2.0: What can the world learn from educational change in Finland? New York, NY: Teachers College Press.

Sarangi, S. (1994). Intercultural or not? Beyond celebration of cultural differences in miscommunication analysis. Pragmatics, 4(3), 409ロ427.

Schatz, M. (2015). Toward one of the leading education-based economies? Investigating aims, strategies, and practices of Finland's education export landscape. Journal of Studies in International Education, 19(4), 327 $\square 340$.

Schatz, M., Popovic, A., \& Dervin, F. (2015). From PISA to national branding: Exploring Finnish education ${ }^{\circledR}$. Discourse: Studies in the Cultural Politics of Education, 38(2),

172 $\square$ 184. doi: 10.1080/01596306.2015.1066311

Schulte, B. (2012). World culture with Chinese characteristics: When global models go native. Comparative Education, 48(4), $473 \square 486$.

Shi, X. (2001). Critical pedagogy and intercultural communication: Creating discourses of diversity, equality, common goals and rational-moral motivation. Journal of Intercultural Studies, 22(3), 279 $\square 293$. doi: 10.1080/07256860120094000 
Simpson, A. (2018). Democracy as othering within Finnish education. International Journal of Bias, Identity, and Diversities in Education, 3(2), 77 $\square 93$. doi: 10.4018/IJBIDE.2018070106

Simpson, A., \& Dervin, F. (2017). Democracy in education: An omnipresent yet distant other. Palgrave communications, 3(24). doi: 10.1057/s41599-017-0012-5.

Tan, C. (2014). Tensions and challenges in China's education policy borrowing. Educational

Research, 58(2), 195 $\square$ 206. doi: 10.1080/00131881.2016.1165551

The Gleaner (2017). Lessons from Finland's "education miracle." Retrieved from

http://jamaica-gleaner.com/article/art-leisure/20170813/lessons-finlands-education-miracle58 Fred DERVIN, Ashley SIMPSON

University World News. (2017). Can Finland capitalise on its educational reputation?

Retrieved from http://www.universityworldnews.com/article.php?story=2017092304391

9555

Varjo, J., Simola, H., \& Rinne, R. (2013). Finland's PISA results: An analysis of dynamics in education politics. In H. D. Meyer \& A. Benavot (Eds.), PISA, power, and policy: The emergence of global educational governance. Oxford, UK: Symposium Books.

Verger, A., Steiner-Khamsi, G., \& Lubienski, C. (2017). The emerging global education industry: Analysing market-making in education through market sociology. Globalisation, Societies and Education, 15(3), 325 $\square 340$. doi: 10.1080/14767724.2017.1330141

Volcic, Z. (2008). Former Yugoslavia on the World Wide Web: Commercialization and branding of nation-states. International Communication Gazette, 70(5), 395 $\square$ 413. doi: $10.1177 / 1748048508094292$

Volcic, Z., \& Andrejevic, M. (2011). Nation branding in the era of commercial nationalism. International Journal of Communication, 5(21), 598ロ618.

Wikan, U. (2002). Generous betrayal. Chicago, CL: Chicago University Press.

Worthen, H. (2009) Tip of the iceberg? Finland and the holocaust. East European Jewish

Affairs, 39(1), 121 $\square 133$, doi: 10.1080/13501670902750337 